Volume 3, Number 2, Agustus 2020

p-ISSN: 2615-0212 | e-ISSN: 2621-2838

https://ejournal.iaifa.ac.id/index.php/dirasah

\begin{tabular}{|c|c|c|}
\hline Accepted: & Revised: & Published: \\
Mei 2020 & Juni 2020 & Agustus 2020 \\
\hline
\end{tabular}

\title{
Pemanfaatan Sumber Belajar Perpustakaan dalam Meningkatkan Keterampilan Membaca pada Mata Pelajaran Bahasa Indonesia Peserta Didik Kelas IV MI Darussalam Pikatan
}

\author{
Khoiruzzaim Kurniawan \\ Institut Agama Islam Faqih Asy'ari Kediri, Indonesia \\ Email:khoiruzzaimkurniawan@gmail.com
}

\begin{abstract}
The research in this study is motivated by a phenomenon that there are several obstacles encountered in the Indonesian language learning process, one of which is the lack of a reading culture in students in the teaching and learning process. This research uses Class Action Research as much as two cycles. Each cycle consists of four stages, namely planning, implementing, observing and reflecting.The results showed an increase in reading skills of students in class IV MI Darussalam Pikatan through the use of library learning resources in the Indonesian subject matter of the main sentence. This can be seen from the measurement of Effective Reading Ability (KEM) conducted by researchers, from the pre-test which only gained an average of 67 words per minute increased in the first cycle post test with 73 words per minute and rose significantly in the second cycle post test with 106 words per minute. The average value of student learning outcomes also increased from the pre test which reached an average of 49, increased in the first cycle post test which is 63 and the second cycle post test increased significantly ie an average of 81. Then it can be concluded that the use of Library Learning Resources can improve reading skills in grade IV MI Darussalam Pikatan Blitar students.
\end{abstract}

Keywords: Learning resources, library, reading skills 


\begin{abstract}
Abstraksi
Penelitian ini didorong oleh suatu fenomena bahwa ada beberapa kendala yang dihadapi dalam proses pembelajaran bahasa Indonesia, salah satunya adalah kurangnya budaya bacaan pada siswa dalam proses belajar mengajar. Hal ini juga diperburuk oleh para guru yang masih menggunakan sumber belajar konvensional saja, sehingga menyebabkan siswa terlihat kurang bersemangat dalam berpartisipasi dalam proses belajar mengajar, karena siswa tidak berperan aktif dalam proses belajar mengajar.Penelitian ini menggunakan Class Action Research sebanyak dua siklus. Setiap siklus terdiri dari empat tahap, yaitu perencanaan, pelaksanaan, pengamatan dan refleksi. Target dari penelitian ini adalah siswa kelas empat materi pelajaran bahasa Indonesia dalam kalimat utama. Hasil penelitian menunjukkan peningkatan kemampuan membaca siswa di kelas IV MI Darussalam Pikatan melalui penggunaan sumber daya belajar Perpustakaan dalam masalah pokok bahasan Indonesia dari kalimat utama. Hal ini dapat dilihat dari pengukuran kemampuan membaca efektif (KEM) yang dilakukan oleh para peneliti, dari pra-tes yang hanya memperoleh rata 67 kata per menit meningkat dalam siklus pertama pasca tes dengan 73 kata per menit dan meningkat secara signifikan dalam siklus kedua pasca tes dengan 106 kata per menit. Nilai rerata dari hasil belajar siswa juga meningkat dari pre Test yang mencapai 49, meningkat pada siklus pertama tes pasca yang 63 dan siklus kedua tes pasca meningkat secara signifikan yaitu rata-rata 81. Kemudian dapat disimpulkan bahwa penggunaan sumber daya belajar Perpustakaan dapat meningkatkan kemampuan membaca di kelas IV MI Pikatan Blitar siswa.
\end{abstract}

Kata kunci: belajar sumber daya, Perpustakaan, membaca keterampilan

\title{
Pendahuluan
}

Setiap makhluk hidup di dunia ini pastilah memerlukan komunikasi. Dalam komunikasi, manusia memerlukan bahasa untuk berinteraksi atau alat untuk berkomunikasi, dalam arti alat untuk menyampaikan pikiran, gagasan, konsep atau perasaan. ${ }^{1} \quad$ Sehingga manusia diharuskan dapat menguasai keterampilan berbahasa yang baik dan benar.

Begitu pentingnya keterampilan berbahasa, sehingga masalah keterampilan berbahasa khususnya keterampilan baca-tulis atau literasi (melek

\footnotetext{
${ }^{1}$ Abdul Chaer dan Leonie Agustina, Sosiolinguistik Perkenalan Awal (Jakarta: Rineka Cipta, 2010). 11.
} 
huruf) menurut Azies dan Alwasilah di seluruh dunia masalah literasi atau melek huruf ini merupakan persoalan manusiawi sepenting dan semendasar persoalan pangan dan papan. ${ }^{2}$ Penguasaan keterampilan bahasa merupakan sebuah syarat mutlak yang harus dimiliki di era komunikasi dan globalisasi saat ini.

Keterampilan berbahasa terbagi dalam empat aspek. Keempat aspek tersebut adalah keterampilan menyimak, berbicara, membaca dan menulis. ${ }^{34}$ Keterampilan membaca merupakan salah satu keterampilan yang harus dikuasai manusia. Keterampilan membaca tidak timbul dengan sendirinya melainkan melalui proses belajar dan latihan secara terus - menerus. Lembaga formal tingkat pendidikan dasar dapat dijadikan sebagai tempat untuk melatih keterampilan berbahasa yang baik dan benar khususnya untuk keterampilan membaca.

Sementara itu keterampilan dalam membaca dan menulis yang telah ditunjukan dan diwariskan nenek moyang sebagaimana yang terhimpun dalam koleksi naskah - naskah kuno seperti Hikayat Hang Tuah dari Melayu, Naskah Cerita Parahyangan dari Sunda, Babad Tanah Jawi dari Jawa, dan La Galigo dari Makasaar. Naskah - naskah tersebut ditulis berabad - abad yang lalu sebagai hasil kreativitas para pendahulu kita yang ditulis dalam berbagai media seperti daun lontar, kulit kayu, dan tulang dengan menggunakan huruf Arab, Melayu, Sunda, Jawa, Bugis dan lain sebagainya. Naskah tersebutmengandung informasi tentang hikayat, babad, silsilah dan berbagai informasi mengenai kehidupan masa silam, mengenai peradaban bangsakita dimasa lalu. Hal tersebut menunjukkan bahwa nenek moyang kita dahulu telah memberikan teladan dalam budaya menulis dan membaca. ${ }^{5}$ Sebenarnya, keterampilan membaca dan menulis sudah diajarkan oleh nenek moyang kita sehingga perlu sekali untuk kita tiru dan lakukan.

2 Azies, Furqonul dan Alwasilah, A. Chaedar. Pengajaran Bahasa Komunikatif: Teori dan Praktek. (Bandung: Remaja Rosdakarya, 1996) 12

${ }^{3}$ Isah Cahyani. Pembelajaran Bahasa Indonesia. (Jakarta : Direktorat Jendral Pendidikan Islam Departemen Agama Republik Indonesia. 2009) 124

${ }^{4}$ http://m4y-a5a.blogspot.com/2012/05/hakikat-membaca.html (diakses : 28/06/2012)

${ }^{5}$ Sambutan Presiden RI pada Pencanangan Gerakan Pemberdayaan Perpustakaan di masyarakat (Jakarta, 17 Mei 2006) dikutip oleh : Sutarno NS. Perpustakaan an Masyarakat. (Jakarta : CV. Sagung Seto, 2006).6.

Dirasah, Vol. 3, No.2, Agustus 2020 
Bahasa Indonesia, merupakan salah satu mata pelajaran yang harus dipelajari pada jenjang pendidikan dasar.Pendidikan Bahasa Indonesia di sekolah dasar bertujuan mengembangkan keterampilan berbahasa Indonesia peserta didik sesuai dengan fungsi bahasa yakni sebagai wahana berpikir dan wahana berkomunikasi untuk mengembangkan potensi intelektual, emosional, dan sosial. ${ }^{6}$

Perkembangan teknologi dan informasi saat ini sangat cepat, sehingga mempengaruhi tuntutan masyarakat terhadap dunia pendidikan baik secara kualitas maupun kuantitas sehingga lembaga pendidikan harus mampu mengikuti perkembangan pendidikan sesuai dengan perkembangan saat ini. Salah satu yang harus dikembangkan oleh lembaga pendidikan sekarang adalah sumber belajar.

Kegiatan proses belajar-mengajar saat ini memandang peserta didik tidak lagi dipandang sebagai objek belajar tetapi peserta didik dipandang sebagai subjek belajar. Peserta didik juga dituntut untuk dapat menemukan pemecahan dari berbagai persoalan yang berkaitan dengan proses belajar, membaca, meneliti, dan berbagai kegiatan lain yang bersifat positif dan produktif, sehingga diperlukan perpustakaan sekolah, laboratorium, alat-alat peraga yang memadai agar proses belajar dapat tercipta secara harmonis dan dinamis.

Konsep pendidikan sekarang tidak lagi menempatkan guru sebagai satusatunya sumber pengetahuan tetapi peserta didik dapat memilih sesuai dengan kebutuhan. Seperti; bertanya kepada teman, observasi, atau datang ke perpustakaan untuk mencari informasi yang dibutuhkan. Perpustakaan sekolah adalah salah satu sumber belajar yang paling ideal di dalam lembaga pendidikan.

Perpustakaan sekolah merupakan salah satu program pendidikan jangka panjang, sehingga pendidikan ini tidak dapat langsung dilihat karena harus melalui suatu proses. ${ }^{7}$ Perpustakaan merupakan sarana yang vital dalam proses belajar-mengajar, oleh karena itu perpustakaan dipandang sebagai jantung program pendidikan.

6 Lely Halimah, Pemberdayaan Lingkungan Sebagai Sumber Belajar dalam Upaya Meningkatkan Kompetensi Berbahasa Indonesia Siswa Kelas 4 SD Laboratorium UPI Kampus Cibiru (JURNAL, Pendidikan Dasar, Nomor: 10 - Oktober 2008) 1

${ }^{7}$ Sinaga, Pengelolaan Perpustakaan Sekolah (Jakarta : Kiblat Buku Utama, 2007), 11 
Berdasarkan pasal 1 Undang - Undang Nomor 43 tahun 2007 tentang Perpustakaan, dijelaskan bahwa perpustakaan adalah institusi pengelola koleksi karya tulis, karya cetak, dan / atau karya rekam secara profesional dengan sistem yang baku guna memenuhi kebutuhan pendidikan, penelitian, pelestarian,informasi, dan rekreasi para pemustaka. ${ }^{8}$ Secara umum, tujuan dari perpustakaan menurut Undang - Undang Republik Indonesia Nomor 43 tahun 2007 pada pasal 4 yaitu untuk memberikan layanan kepada pemustaka, meningkatkan kegemaran membaca, serta memperluas wawasan dan pengetahuan untuk mencerdaskan kehidupan bangsa. ${ }^{9}$

Kebutuhan akan adanya perpustakaan sekolah timbul dari proses pendidikan itu sendiri, sehingga banyak hal yang seharusnya perlu dilayani oleh perpustakaan sekolah seperti memperkaya bahan mengajar, melengkapi alat-alat peraga yang diharapkan dapat menunjang efektifitas dan efisiensi belajarmengajar, menyediakan berbagai sumber informasi, sumber belajar dan lain sebagainya. Perpustakaan sekolah sangat bermanfaat dalam penyelenggaraan dan proses belajar-mengajar, sehingga setiap sekolah diharuskan untuk menyediakan perpustakaan karena perpustakaan merupakan bagian dari kegiatan sekolah. ${ }^{1011}$

Perpustakaan sebagai pusat sumber daya informasi menjadi tulang punggung gerak majunya suatu instansi, terutama instansi pendidikan, tempat tuntutan untuk adaptasi terhadap perkembangan informasi sangat tinggi. Hal ini dikarenakan pengguna dominasi dari kalangan akademisi yang kebutuhannya akan informasi begitu kuat sehingga mau tidak mau perpustakaan harus berpikir pula untuk berupaya mengembangkan diri guna memenuhi kebutuhan pengguna. $^{12}$

\footnotetext{
${ }^{8}$ Undang-undang Republik Indonesia Nomor 43 tahun 2007 tentang Perpustakaan. (Jakarta : Perpustakaan Nasional, 2007), 2

${ }^{9}$ Ibid, 4

${ }^{10}$ Undang - Undang Nomor20 Tahun 2003 tentang Sistem Pendidikan Nasional. (Jakarta : Sinar Grafika), 18 dan 23

${ }^{11}$ Peraturan Pemerintah Nomor 19 Tahun 2005 tentang Standar Nasional Pendidikan (Jakarta : Fokusmedia, 2010), 22.

${ }^{12}$ Wiji Suwarno. Ilmu perpustakaan \& Kode Etik Pustakawan. (Jogjakarta : AR - RUZZ Media Group, 2010), 15.
}

Dirasah, Vol. 3, No.2, Agustus 2020 
Tetapi, realita sekarang terdapat beberapa sekolah yang sudah mempunyai unit perpustakaan, namun tidak berjalan secara semestinya. Hal ini dipertegas Sutarno seperti pernyataannya di bawah ini :

Berdasarkan data tentang perpustakaan sekolah dan lembaga pendidikan yang lain seperti perpustakaan umum yang dijelaskan sebagai berikut (1) pada 200.000 Sekolah Dasar diperkirakan hanya sekitar 1\% memiliki perpustakaan standar (2) dari 70.000 Sekolah Lanjutan Tingkat Pertama diperkirakan hanya sekitar 34\% yang memiliki perpustakaan standar (3) dari 14.000 Sekolah Menengah Umum hanya sekitar 54\% yang memiliki perpustakaan standar (4) dari sekitar 4.000 Perguruan tinggi hanya kurang lebih 60\% yang mempunyai perpustakaan standar. Kondisi demikian yang memang dirasakan, untuk kategori umum desa atau kecamatan tidak lebih dari 0,5\% yang memiliki perpustakaan standar. Kondisi demikian yang memang dirasakan memprihatinkan oleh sebab itu perlu upaya yang dilakukan secara konsisten dalam rangka mewujudkan perpustakaan yang representative dalam pengertian mampu bekerja dan memberikan layanan yang baik. ${ }^{13}$

Berdasarkan hasil observasi dan pengamatan yang dilakukan peneliti terhadap peserta didik kelas IV MI Darussalam Pikatan, terdapat beberapa kendala yang dihadapai dalam proses pembelajaran Bahasa Indonesia, salah satunya adalah dalam proses belajar mengajar guru yang masih menggunakan sumber belajar konvensional saja, seperti, informasi dari guru dan LKS. Hal ini mengakibatkan peserta didik terlihat kurang bersemangat dalam mengikuti proses belajar mengajar, karena peserta didik tidak berperan aktif dalam proses kegiatan belajar mengajar. Sehingga dapat mempengaruhi hasil belajar peserta didik juga akan menurun.

Dengan pemanfaatan sumber belajar perpustakaan, berarti mengajak peserta didik untuk memilih sumber belajar mana yang menarik dalam proses belajar mengajar. Diharapkan peserta didik mengalami peningkatan hasil belajarnya, termotivasi dalam belajar, aktif bertanya, kreatif, dan bergairah dalam belajar dikelas dan dirumah serta sikap cinta membaca. Dengan membawa kecintaan membaca pada peserta didik diharapkan membentuk budaya membaca. Secara tidak langsung dengan terbentuknya budaya membaca

\footnotetext{
${ }^{13}$ Sutarno, Perpustakaan dan Masyarakat, (Jakarta : CV. Agung Seto, 2006), 47.
} 
pada anak dapat meningkatkan kualitas ilmu pengetahuan pada peserta didik dipelbagai mata pelajaran yang diajarkan khususnya pada bidang bahasa.

Budaya membaca harus ditanamkan sejak dini agar terciptanya masyarakat cerdas yang dicita - citakan oleh bangsa Indonesia. Sayangnya, kegemaran itu belum melekat pada masyarakat kita. Rofi'uddin dan Zuhdi mengungkapkan bahwa rendahnya kemampuan lulusan sekolah dasar dalam hal baca-tulis terus dikumandangkan, bahkan hasil penelitian kemampuan membaca tingkat sekolah dasar yang dilaksanakan oleh The InternationalAssociation for the Evaluation of Educational Achievement (IEA) tahun 1992 menunjukkan bahwa kemampuan membacapeserta didik sekolah dasar di Indonesia berada padaurutan ke 26 dari 27 negara yang menjadi sampelpenelitian. Tepatnya kemampuan membaca peserta didiksekolah dasar di Indonesia terendah di kawasan ASEAN.Lebih parah lagi Ismail dalam Jalal dan Supriadi dalam Ahmad Rofiudin dan ZuhriDarmiyati mengemukakan hasil observasinya di beberapa negarabahwa anak-anak Indonesia "Rabun membaca dan lumpuhmenulis". ${ }^{14}$

Pada saat usia anak antar umur 9 samapai 11 tahun perkembangan bahasa anak mulai berkembang. Seperti sebuah studi yang dilakukan tahun 2007 menemukan bahwa perbendaharaan kata - kata lisan berhubungan dengan kemampuan membaca serta memahami. Para peneliti menemukan bahwa anak yang memiliki kosakata lisan yang baik cenderung lebih lancar dalam membaca kata - kata sulit dan memahaminya, sedangkan anak yang memiliki pemahaman membaca yang kurang menunjukkan kelemahan dalam membaca kata - kata sulit serta kosakata lisan. ${ }^{15}$

Berdasarkan penelitian diatas dapat disimpulkan bahwasanya membaca sangat berkaitan erat dengan perkembangan bahasa pada anak. Anak yang sering membaca lebih berkembang bahasanya dari pada anak yang kurang gemar membaca. Dari sinilah peneliti ingin mecoba mencari jalan keluar mengenai cara meningkatkan keterampilan membaca anak dengan mendekatkan mereka kepada perpustakaan.

\footnotetext{
${ }^{14}$ Rofi'uddin, Ahmad dan Zuhdi, Darmiyati. Pendidikan Bahasa dan Sastra Indonesia di KelasTinggi. (Jakarta: Depdikbud, 1999), 37.

${ }^{15}$ Coral Cooper. Penerjemah : Nadia Lastiani. Ensklopedia Pengembangan Anak. Judul Asli :Your Child year by Year. ( Jakarta : Erlangga, 2008), 231.
} 
Sesuai dengan pemikiran di atas, maka peneliti tertarik untuk mengangkat judul Penelitian ni dengan judul "Pemanfaatan Sumber Belajar Perpustakaan dalam Meningkatkan Keterampilan Membaca Pada Mata Pelajaran Bahasa Indonesia Peserta didik Kelas IV MI Darussalam PikatanTahun Pejaran 2019/2020"

\section{Metode Penelitian}

\section{Jenis dan Desain Penelitian}

Penelitian pada hakikatnya adalah suatu kegiatan ilmiah untuk memperoleh pengetahuan yang benar tentang suatu masalah. ${ }^{16} \mathrm{Jenis}$ penelitian ini adalah Penelitian Tindakan Kelas (Classroom Action Research). Penelitian Tindakan Kelas adalah proses investigasi terkendali untuk menemukan dan memecahkan masalah pembelajaran di kelas, proses pemecahan masalah itu dilakukan secara bersiklus dengan tujuan untuk meningkatkan kualitas proses dan hasil pembelajaran di kelas tertentu. ${ }^{17}$ Menurut McNiff seperti yang dikutip oleh Supardi memandang bahwa Penelitian Tindakan Kelas (PTK) sebagai bentuk penelitian reflektif yang dilakukan oleh pendidik terhadap kurikulum pengembangan sekolah, meningkatkan prestasi belajar, pengembangan keahlian mengajar, dan sebagainya. ${ }^{18}$

Menurut Madya dalam Suroso dalam Penelitian Tindakan Kelas (PTK) partisipatoris adalah peneliti harus ada di sekolah dari awal penelitiannya dalam menganalisis keadaan dan melihat kesenjangan antara keadaan nyata dengan keadaan yang diinginkan, merumuskan rencana tindakan, kemudian ikut melaksanakan rencana tersebut dan memantaunya serta melaporkan hasil penelitian. ${ }^{19}$ Tujuannya adalah untuk meningkatkan kualitas praktik pembelajaran, memberikan sumbangan kepada perkembangan teori pembelajaran atau kependidikan, dan peningkatan karier guru. ${ }^{20}$

Model siklus yang digunakan pada penelitian ini adalah dengan menggunakan model siklus yang dikemukakan oleh Kemmis \& Taggart yang

\footnotetext{
${ }^{16}$ Ahmad Tanzeh, Metodologi Penelitian Praktis, (Yogyakarta: Penerbit Teras, 2011 ), 1-2

17 Sa'dun Akbar, Penelitian Tindakan Kelas, (Filosofi, Metodologi, dan Implementasinya, (Malang: Surya Pena Gemilang, 2008), 28.

${ }^{18}$ Suharsimi Arikunto, dkk.,Penelitian Tindakan Kelas, (Jakarta: Bumi Aksara, 2008), 102.

${ }^{19} \mathrm{Ibid} ., 36$.

${ }^{20}$ Mohammad Asrori, Penelitian Tindakan Kelas, (Bandung: Wacana Prima, 2007), 45.
} 
terdiri Empat kegiatan utama yang ada pada setiap siklus, yaitu (a) perencanaan, (b) tindakan, (c) pengamatan, dan (d) refleksi. ${ }^{21}$

a) Perencanaan

Tahapan ini berupa menyusun rancangan tindakan yang menjelaskan tentang apa, mengapa, kapan, di mana, oleh siapa, dan bagaimana tindakan tersebut akan dilakukan. Kegiatan perencanaan ini mencakup :22

1. Identifikasi masalah

2. Analisis penyebab adanya masalah

3. Pengembangan bentuk tindakan (aksi) sebagai pemecahan masalah

b) Tindakan

Dalam menentukan bentuk tindakan yang dipilih perlu mempertimbangkan pertanyaan-pertanyaan sebagai berikut : ${ }^{23}$

1) Apakah tindakan yang dipilih telah mempunyai landasan berpikir yang mantap, baik secara kajian teoritis maupun konsep?

2) Apakah alternatif tindakan yang dipilih dipercayai dapat menjawab permasalahan yang muncul?

3) Bagaimanakah cara melaksanakan tindakan dalam bentuk strategi langkah-langkah setiap siklus pembelajaran di kelas?

4) Dan bagaimanakah cara menguji tindakan sehingga dapat dibuktikan telah terjadi perbaikan kondisi dan peningkatan proses dalam kegiatan pembelajaran di kelas yang diteliti?

Pada tahap ini, rencana tindakan penerapan pembelajaran akan diterapkan. Rencana tindakan tersebut tentu saja sebelumnya telah dipersiapkan kepada si pelaksana tindakan (peneliti) untuk dapat diterapkan di dalam kelas. ${ }^{24}$

c) Observasi

Pada tahap ini, peneliti melakukan pengamatan dan mencatat semua hal yang diperlukan dan terjadi selama pelaksanaan tindakan berlangsung. Pengumpulan data ini dilakukan dengan menggunakan format observasi atau penilaian yang telah disusun, termasuk juga pengamatan secara cermat pelaksanaan rencana tindakan dari waktu ke waktu serta dampaknya

${ }^{21}$ Suhardjono, Penelitian Tindakan Kelas Sebagai Kegiatan Pengambangan Profesi Guru (Jakarta: PT Bumi Aksara, 2007), 74.

${ }^{22}$ Susilo, Penelitian Tindakan Kelas, (Yogyakarta: Pustaka Book Publisher, 2007), 20.

${ }^{23}$ Ibid, 21.

${ }^{24}$ Suharsimi Arikunto, dkk, Penelitian Tindakan Kelas..., 76.

Dirasah, Vol. 3, No.2, Agustus 2020 
terhadap proses dan hasil belajar. ${ }^{25}$ Beberapa hal yang perlu diperhatikan dalam pengambilan data berkaitan dengan observasi ini adalah $:^{26}$

1. Jenis data yang dihimpun memang diperlukan dalam rangka implementasi tindakan perbaikan.

2. Indikator-indikator yang ditetapkan harus tergambarkan pada perilaku peserta didik dan guru secara terstruktur.

3. Kesesuaian prosedur pengambilan data.

4. Pemanfaatan data dalam analisis dan refleksi.

Pada saat melakukan observasi peneliti dapat juga merekam dengan handy cam atau foto, mewawancarai peserta didik dan guru, portofolio, perangkat pembelajaran dan tes. ${ }^{27}$

d) Refleksi

Langkah ini merupakan sarana untuk melakukan pengkajian kembali tindakan yang telah dilakukan terhadap subjek penelitian. ${ }^{28}$ Dalam proses refleksi peneliti melakukan pemikiran ulang terhadap yang sudah dilakukan, apa yang belum dilakukan, apa yang sudah dicapai, masalah apa saja yang belum terpecahkan, dan menentukan tindakan apa lagi yang perlu dilakukan untuk meningkatkan kualitas proses dan hasil pembelajaran yang akan dilanjutkan pada siklus ke II. ${ }^{29}$

Kemmis dan Mc Taggart dalam Sukardi menyatakan bahwa model penelitian tindakan kelas berbentuk sistem spiral yang saling terkait antara siklus yang satu ke siklus selanjutnya. ${ }^{30}$ Di bawah ini adalah salah satu bentuk siklus PTK model Kemmis dan Mc Taggart. ${ }^{31}$

\footnotetext{
${ }^{25}$ Ibid, 78.

${ }^{26}$ Susilo, Penelitian Tindakan Kelas ...., 23.

${ }^{27}$ Sa'dun Akbar, Penelitian Tindakan Kelas..., 43.

${ }^{28}$ Sukardi, Metodologi Penelitian Pendidikan...,. 213

${ }^{29}$ Sa'dun Akbar, Penelitian Tindakan Kelas...,. 92

${ }^{30}$ Sukardi, Metodologi Penelitian Pendidikan, (Jakarta: Bumi Aksara, 2007), 214

${ }^{31}$ Suharsimi Arikunto, dkk, Penelitian Tindakan Kelas, (Jakarta: Bumi Aksara, 2007), 16
} 
Gambar 3.1 Siklus PTK model Kemmis dan MC Taggart

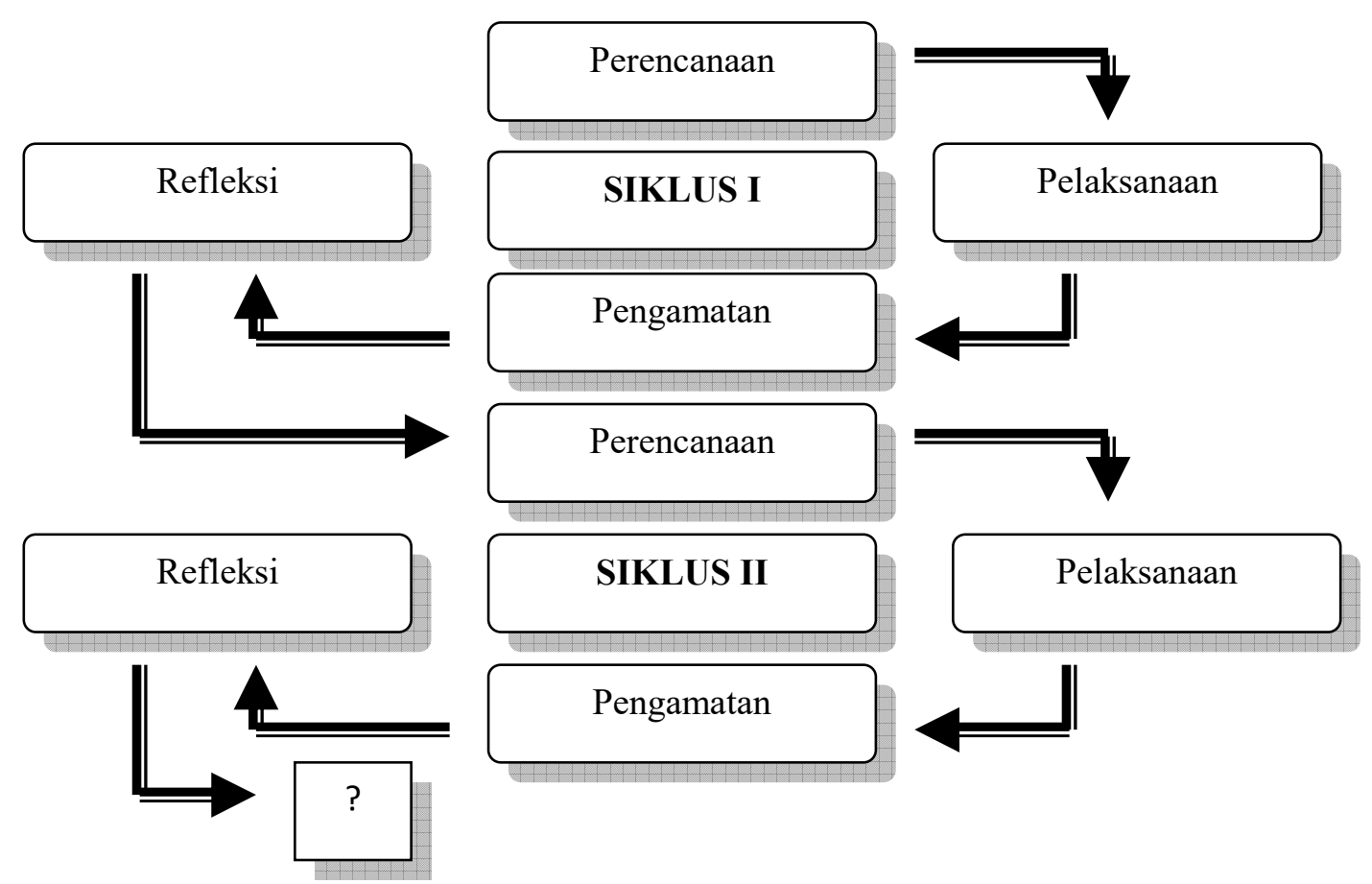

Siklus Penelitian Tindakan Kelas pada penelitian ini dipersiapkan untuk 5 kali pertemuan yang semuanya dibentuk dalam skenario pembelajaran untuk satu kompetensi dasar. Penelitian dilakukan di satu kelas yaitu kelas IV A MI Darussalam Pikatan.

Penelitian ini dilaksanakan sebanyak dua siklus yang terdiri dari 5 pertemuan. Siklus I terdiri dari tiga kali pertemuan, dan siklus II dua kali pertemuan.

\section{Objek Penelitian}

Lokasi tempat dilaksanakannya penelitian ini adalah MI Darussalam Pikatan Blitar tahun pelajaran 2019 - 2020 dengan alamat Jalan Raya Pikatan Kecamatan Wonodadi Kabupaten Blitar, Fax.0313724627, Wabside: midarussalampikatanii.net.id, kode pos : 66218, telpon : (0355) 333910. Objek penelitian adalah peserta didik kelas IV A MI Darussalam Pikatan Blitar, dengan jumlah 24 peserta didik, yang terdiri dari10 peserta didik laki - laki dan 14 peserta didik perempuan. Hal tersebut memudahkan pembelajaran dan tujuan 
pembelajaran akan mudah dicapai. Akan tetapi masih jarang sekali digunakan variasi sumber belajar, masih menggunakan sumber belajar yang monoton sehingga perlu di aplikasikan ke sumber belajar yang baru yang lebih efektif dan efisien. Sehingga peneliti akan menerapkan sumber belajar perpustakaan dengan materi membaca intensif agar keterampilan membaca peserta didik dapat meningkat.

Lokasi ini dipilih sebagai tempat penelitian dengan pertimbangan:

1. Adanya perpustakaan sekolah yang memadai,

2. Dalam pembelajaran Bahasa Indonesia selama ini belum memaksimalkan pemanfaatkan sarana Perpustakaan sebagai sumber belajar walaupun sudah tersedia,

3. Pembelajaran Bahasa Indonesia yang dilakukan selama ini lebih kearah guru yang memanfaatkan sumber belajar dengan menggunakan benda yang tak langsung dan cenderung mengabaikan sumber - sumber belajar yang ada disekitarnya seperti perpustakaan.

\section{Teknik Pengumpulan Data}

Pengumpulan data pada penelitian ini dilakukan dengan menggunakan teknik sebagai berikut :

1. Observasi

Observasi adalah kegiatan pengamatan (pengambilan data) untuk mengetahui seberapa jauh efek tindakan telah mencapai sasaran. ${ }^{32}$ Menurut S. Margono dalam Nurul observasi diartikan sebagai pengamatan dan pencatatan secara sistematis terhadap gejala yang tampak pada objek penelitian. Pengamatan dan pencatatan ini dilakukan terhadap gejala yang tampak pada objek penelitian. ${ }^{33}$ Pengertian lain dari observasi adalah upaya merekam segala peristiwa dan kegiatan yang terjadi selama tindakan perbaikan itu berlangsung dengan atau tanpa alat bantuan. ${ }^{34}$

\footnotetext{
${ }^{32}$ Ibid., 127

${ }^{33}$ Nurul Zuriah, Metodologi Penelitian Sosial dan Pendidikan (Jakarta: Bumi Aksara, 2006), 173

${ }^{34}$ Tatag Yuli Eko Siswono, Mengajar dan Meneliti Panduan PTK untuk Guru dan Calon Guru, (Surabaya: Unesa University Press, 2008), 25
} 
2. Wawancara

Wawancara adalah teknik pengumpulan data dengan interview pada satu atau beberapa orang yang bersangkutan. ${ }^{35}$ Dalam pengertian lain, wawancara adalah suatu cara untuk mengetahui situasi tertentu di dalam kelas dilihat dari sudut pandang orang lain. ${ }^{36}$ Wawancara juga dapat diartikan sebagai percakapan dengan maksud tertentu. Percakapan itu dilakukan oleh dua pihak, yaitu pewawancara (interviewer) yang mengajukan pertanyaan dan yang diwawancarai (interviewee) yang memberikan jawaban atas pertanyaan itu. ${ }^{37}$

3. Tes

Tes adalah suatu cara mengumpulkan data dengan memberikan tes kepada objek yang diteliti. ${ }^{38}$ Pedapat lain menyatakan bahwa tes ialah seperangkat rangsangan yang diberikan kepada seseorang dengan maksud untuk mendapatkan jawaban-jawaban yang dapat dijadikan dasar bagi penetapan skor angka. ${ }^{39}$

4. Dokumentasi

Yaitu mengumpulkan data dengan melihat atau mencatat suatu laporan yang sudah tersedia. ${ }^{40}$ Dokumen dapat berupa secarik kertas yang berisi tulisan mengenai kenyataan, bukti, ataupun informasi, dapat pula berupa foto, pita kaset atau pita recording, slide, mikro film, dan film. Oleh sebab itu dokumen dalam hal ini dapat berupa arsip. ${ }^{41}$ Metode ini dilakukan dengan melihat dokumen-dokumen resmi seperti monografi, catatancatatan serta buku-buku peraturan yang ada. Dokumen sebagai metode pengumpulan data adalah setiap persyaratan tertulis yang disusun oleh seseorang atau lembaga untuk keperluan pengujian suatu peristiwa atau menyajikan akunting.

\footnotetext{
${ }^{35}$ Ahmad Tanzeh, Metodologi Penelitian Praktis, (Yogyakarta: Teras, 2011), 89

${ }^{36}$ Rochiati Wiriaatmadja, Metode Penelitian..., 117

${ }^{37}$ Lexy Moleong, Metodologi Penelitian Kualitatif (Bandung: PT. Remaja Rosdakarya, 2002), 135

${ }^{38}$ Ibid.,. 91

${ }^{39}$ Arief Furchan, Pengantar Penelitian dalam Pendidikan (Surabaya: Usaha Nasional, tt) 256

${ }^{40}$ Ahmad Tanzeh, Metodologi Penelitian..., 92

${ }^{41}$ M. Iqbal Hasan, Pokok Materi Metodologi Penelitian Dan Amplikasinya (Jakarta: Ghalia Indonesia, 2002) 87
}

Dirasah, Vol. 3, No.2, Agustus 2020 
Alasan dokumen dijadikan sebagai data untuk membuktikan penelitian karena dokumen merupakan sumber yang stabil, dapat berguna sebagai bukti untuk pengujian, mempunyai sifat yang alamiah, tidak reaktif, sehingga mudah ditemukan dengan teknik kajian isi, disamping itu hasil kajian isi akan membuka kesempatan untuk memperluas pengetahuan terhadap sesuatu yang diselidiki. ${ }^{42}$

5. Catatan Lapangan

Catatan lapangan digunakan sebagai pelengkap data penelitian sehingga diharapkan semua data yang tidak termasuk dalam observasi dapat dikumpulkan pada penelitian ini.

\section{Teknik Analisis Data}

Menurut Miles dan Huberman dalam Rochiati model ideal dari pengumpulan data dan analisis adalah yang secara bergantian berlangsung sejak awal. Jadi, analisis data yang dilakukan pada penelitian tindakan kelas dilakukan sejak awal orientasi lapangan. ${ }^{43}$

Miles dan Huberman dalam Sugiyono mengemukakan bahwa aktifitas dalam analisis data kualitatif dilakukan secara interaktif dan berlangsung secara terus menerus sampai tuntas, sehingga datanya sudah penuh. Aktifitas dalam analisis data yaitu reduksi data, penyajian data, penarikan kesimpulan/verifikasi data ${ }^{44}$.

\section{Indikator Keberhasilan}

Pada penelitian ini, indikator keberhasilan peserta didik menggunakan sistem penilaian acuan patokan (PAP), yakni batas lulus purposif (ditentukan berdasarkan kriteria tertentu).

Penilaian acuan patokan (PAP) adalah penilaian yang diacukan kepada tujuan instruksional yang harus dikuasai oleh peserta didik. Peserta didik dikatakan berhasil apabila ia menguasai atau mencapai sekitar 75-80 persen dari

\footnotetext{
${ }^{42}$ Ibid., 93

${ }^{43}$ Rochiati Wiriaatmadja, Metode Penelitian..., 139

${ }^{44}$ Sugiyono, Metodologi Penelitian Kuantitatif dan Kualitatif, (Bandung: Alfabeta, 2008), 246
} 
tujuan yang seharusnya dicapai atau sekurang-kurangnya (75\%)". ${ }^{45}$ Kurang dari kriteria tersebut dinyatakan belum berhasil. ${ }^{46}$

Indikator Keberhasilan dalam penelitian ini ditentukan kriterianya, yaitu 75 persen. Rumusnya adalah $:^{47}$

$$
\mathrm{S}=\frac{\mathrm{R}}{\mathrm{N}} \times 100
$$

Keterangan:

S: Nilai yang dicari/diharapkan

R: Jumlah skor dari item/soal yang dijawab benar

$\mathrm{N}$ : skor maksimal ideal dari tes tersebut.

\section{Prosedur Penelitian}

Adapun prosedur penelitian yang dilakukan dalam penelitian ini ada dua tahap. Pertama tahap pra tindakan dan kedua tahap pelaksanaan tindakan. Penelitian ini juga dilakukan melalui 2 siklus yaitu siklus 1 dan siklus 2 .

Rincian tahap-tahap pada penelitian ini adalah sebagai berikut:

a. Tahap Pra Tindakan

Kegiatan pratindakan memuat studi pendahuluan yang dilakukan oleh peneliti untuk mendata permasalahan pembelajaran di kelas yang akan diteliti. Kegiatan pratindakan memuat beberapa kegiatan yakni

1) Melakukan dialog dengan kepala sekolah tentang penelitian yang akan dilakukan.

2) Melakukan dialog dengan guru bidang studi Bahasa Indonesia kelas IV MI Darussalam PikatanTulungagung tentang pembelajaran bahasa indonesia dengan memanfaatkan perpustakaan sebagai sumber belajar.

3) Menentukan sumber data.

4) Menentukan subyek penelitian.

5) Membuat soal tes awal.

6) Melakukan tes awal.

b. Tahap Pelaksanaan Tindakan

1) Perencanaan Tindakan

\footnotetext{
${ }^{45}$ E. Mulyasa, Kurikulum Berbasis Kompetensi, (Bandung: Remaja Rosdakarya, 2003), 101102

${ }^{46}$ Nana Sujana,Penilaian hasil proses belajar mengajar, (Bandung: Remaja Rosdakarya, 2006) 8

${ }^{47}$ Ngalim Purwanto, Prinsip-Prinsip ...., 112
}

Dirasah, Vol. 3, No.2, Agustus 2020 
Adapun perencanaan tindakan ini berdasarkan pada observasi awal yang menjadi perencanaan tindakan dengan mengidentifikasi permasalahan yang ada kemudian diambil tindakan pemecahan masalah yang dipandang tepat. ${ }^{48}$

2) Pelaksanaan Tindakan

Tahap pelaksanaan tindakan yaitu melaksanakan kegiatan pembelajaran sesuai dengan RPP, meliputi penyajian materi, praktik lapangan / perpustakaan, pemberian pengarahan, dan penghargaan.

3) Observasi

Observasi dilakukan dengan tujuan agar memperoleh informasi yang lebih mendalam tentang data aktivitas peneliti dan peserta didik mulai dari awal sampai akhir pembelajaran. Hasil observasi dicatat dalam lembar observasi.

4) Refleksi

Refleksi digunakan untuk mengukur keberhasilan pada suatu siklus dan dilakukan pada setiap akhir siklus. Kegiatan ini untuk melihat keberhasilan dan kelemahan dari suatu perencanaan yang dilaksanakan pada siklus 1 . Refleksi juga merupakan acuan dalam menentukan perbaikan atas kelemahan pelaksanaan siklus sebelumnya untuk diterapkan pada siklus selanjutnya.

Seperti halnya siklus 1, pada siklus 2 ini juga mencakup kegiatan perencanaan, pelaksanaan tindakan dan observasi, refleksi, dan perbaikan rencana. Kegiatan pada setiap tahapan pada siklus ke 2 ini akan disesuaikan dengan masalah-masalah proses dan hasil pembelajaran yang terjadi pada siklus 1, apa yang belum dicapai pada siklus 1 akan dilanjutkan dan diperbaiki pada siklus2.

\section{Laporan Hasil Penelitian}

\section{Deskripsi Latar Objek Penelitian}

Penelitian ini dilakukan di MI Darussalam Pikatan, yaitu pada peserta didik kelas IVA. Adapun yang diteliti adalah pembelajaran dengan Pemanfaatan Sumber Belajar Perpustakaan untuk meningkatkan keterampilan membaca peserta didik pada kelas IV di MI Darussalam Pikatan. Oleh karena

\footnotetext{
${ }^{48}$ Kokom Komalasari, Pembelajaran Kontekstual(Bandung : PT Rafika Aditama, 2001),61-62
} 
itu untuk mendapatkan gambaran yang jelas tentang objek penelitian, peneliti akan mendeskripsikan MI Darussalam Pikatansecara keseluruhan sebagai berikut:

\section{a. Paparan Data}

\section{Paparan Data Pra Tindakan}

Pada hari Senin, 08 Januari 2013 peneliti mengadakan pertemuan dengan Ustadzah Siti Samiyatun, S.Ag selaku kepala MI Darussalam Pikatan. Pada pertemuan tersebut, peneliti menyampaikan keinginan untuk melakukan penelitian di sekolah tersebut. Kepala Sekolah tidak keberatan dan menyambut baik maksud peneliti untuk mengadakan penelitian dengan harapan penelitian tersebut dapat memberikan sumbangsih besar dalam proses pembelajaran di sekolah tersebut.

Untuk selanjutnya kepala sekolah memberikan saran untuk menemui wali kelas IV untuk membicarakan lebih lanjut mengenai penelitian yang akan dilakuakan. Sesuai dengan saran kepala sekolah, pada hari itu juga peneliti bertemu dengan wali kelas IV. Di MI Darussalam Pikatansetiap jentang terdiri dari 2 atau 3 kelas, misalnya : 1A, 1-B, II-A, II-B dan lain sebagainya. Pada saat itu peneliti menemui wali kelas IV-A yaitu Ustadzah Titin Muta'ati, S.Pd.I dikarenakan wali kelas IV-B berhalangan hadir di Sekolah. Peneliti memberikan gambaran tentang penelitian yang akan diadakan di kelas IV, wali kelas IV sangat menyambut baik rencana penelitian tersebut.

Peneliti mulai berdiskusi kepada usdzah Titin mengenai pelajaran apa saja yang sulit bagi peserta didik. Ustdzah Titin memberikatan keterangan bahwa pelajaran apa yang dirasa sulit bagi peserta didik. Lalu peneliti menanyakan bagaimana minat baca peserta didik kelas IV-A. Beliau menjelaskan bahwa secara keseluruhan peserta didik kurang begitu berminat dengan kegiatan membaca. Peneliti menawarkan untuk melakukan penelitian dengan memanfaatkan perpustakaan untuk meningkatkan keterampilan membaca peserta didik kelas IV-A melalui pembelajaran Bahasa Indonesia.Wali kelas IV-A menanggapinya dengan positif.

Pada pertemuan tersebut peneliti juga berdiskusi mengenai jumlah peserta didik, kondisi peserta didik dan latar belakang peserta didik. 
Berdasarkan data yang diperoleh wali kelas IV-A, jumlah peserta didik kelas IV seluruhnya adalah 23 peserta didik yang terdiri dari 10 peserta didik laki - laki dan 13 peserta didik perempuan. Sesuai dengan kondisi kelas pada umumnya, kemampuan peserta didik sangat heterogen dilihat dari latar belakang peserta didik bermacam - macam, yaitu dari keluarga, wirausaha, swasta, petani, pedagang, buruh dan pegawai.

Karena penelitian ini menfokuskan tentang pemanfatan penggunaan perpustakaan sebagai sumber belajar, wali kelas IV-A mengusulkan agar memproses perizinan penggunaan perpustakaan untuk digunakan dalam PTK. Peneliti menindak lanjuti usulan tersebut dengan menemui kepala Perpustakaan MI Darussalam PikatanUstadz Irwan Nain, S.Ag yang kebetulan pada waktu itu tidak berada ditempat. Akhirnya proses perizinan peneliti lakukan dengan menemui Ustadzah. Fatimah, S.Ag (Staf Perpustakawan). Pihak perpustakaan menanggapinya dengan baik dan mempersilahkannya.

Pada tanggal 11 Januari 2013 peneliti (P) menemui kembali Ustadzah Titin Muta'ati, S.Pd.I (G) untuk melakukan wawancara terkait informasi awal sebelum melakukan penelitian. Berikut adalah cuplikan wawancara tersebut:

$\mathrm{P}$ : Apakah disekolah SDI ini mempunyai perpustakaan?

G : Ya, MI Darussalam Pikatanmempunyai perpustakaan yang bahan koleksinya kurang lebih 5000 eksemplar

$\mathrm{P}$ : Apakah perpustakaan itu sering digunakan dalam kegiatan belajar mengajar?

G : Sering, karena pihak sekolah mempunyai kebijakan dengan adanya kunjungan wajib yang dilakukan dari Play Grop, TK sampai SDI sendiri yang sudah dibuat secara sistematis

$\mathrm{P}$ : Bagaimanakah kondisi kelas IV ketika proses pembelajaran Bahasa Indonesia berlangsung ?

G : Cukup kondusif, walaupun sering terjadi beberapa kegaduhan tetapi semuanya masih dalam proses KBM (Kegiatan Belajar Mengajar)

P : Pernahkah bapak/ibu guru dalam pembelajaran Bahasa Indonesia dengan materi membaca intensif menggunakan sumber belajar 
selain dari buku paket dan LKS ?

$\mathrm{G}$ : Belum pernah melakukan.

$\mathrm{P}$ : Bagaimana hasil belajar peserta didik kelas IV pada pelajaran Bahasa Indonesia dengan materi membaca?

G : Hasil belajar mereka cukup baik, namun masih terkendala sulitnya mereka menemukan kalimat utama dalam suatu bacaan. Apalagi dengan bacaan yang ada teks dialognya.

$\mathrm{P}$ : Bagaimanakah nilai rata-rata peserta didik pada pelajaran Bahasa Indonesia?

$\mathrm{G}$ : Nilai rata - rata mereka cukup baik dan sudah memenuhi KKM

$\mathrm{P}$ : Pernahkan ibu mengajarkan materi bahasa indonesia dengan cara praktik langsung?

$\mathrm{G}$ : Pernah, biasanya dengan membuat artikel

P : Lalu, pernahkah materi "Kalimat Utama" diajarkan dengan menggunakan sumber belajar perpustakaan?

G : Belum pernah karena jarak antara kelas dengan Gedung perpustakaan cukup jauh.

P : Bagaimana tanggapan ibu jika materi "kalimat utama" diajarkan dengan menggunakan sumber belajar perpustakaan?

G : Menurut saya itu perlu dicoba sebagai referensi para guru MI Darussalam Pikatan. Jika hasil yang didapat sangat baik maka akan digunakan sebagai model Belajar mengajar bagi guru - guru.

Dari hasil wawancara di atas dapat diketahui bahwa pembelajaran mata pelajaran Bahasa Indonesia di kelas IV lebih menekankan pada aspek kognitif, yaitu Pemahaman dengan teori - teori tentang masalah yang dihadapi dan sedikit melakukan praktek ataupun penggunaan sumber belajar selain buku. Walaupun nilai KKM mereka sudah memenuhi, akan tetapi lebih baik jika peserta didik dapat mempraktekkan apa yang mereka peroleh dari hasil pembelajaran di kelas. Sesudah itu peneliti meminta izin untuk melakukan Penelitian pada jam Bahasa Indonsia diajarkan. Ustdzah Titin memberikan izin dan memberikan jadwal pelajaran Bahasa Indonesia kepada peneliti. Pada saat itu kami menyepakati bahwa Penelitian dimulai pada tanggal 14 Januari 2020. 
Wawancara peneliti (Pn) lanjutkan dengan kepala perpustakan MI Darussalam Pikatanyang ternyata tidak ada ditempat. Sehingga peneliti mewawancari staf Perpustakaan $(\mathrm{Pw})$ sekaligus wakil dari pihak perpustakaan. Berikut kutipan wawancara tersebut :

Pn : sejak kapan perpustakaan ini didirikan?

$\mathrm{Pw} \quad$ : sejak 12 tahun yang lalu, perpustakaan ini resmi dibuka pada ınggal 9 Juli 2008

Pn : pakah sudah dibentuk struktur kepengurusan yang ada di :mbaga perputakaan MI Darussalam Pikatan?

Pw : udah ada struktur kepengurusan pada perpustakaan ini

Pn : znis koleksi apasaja yang ada di perpstakaan MI Darussalam ikatan?

Pw : znis koleksi disini dapat dikatakan terlengkap dikalangan ekolah Dasar atau sederajat di kabupaten Tulungagung yang ıeliputi koleksi tentang karya umum, filsafat, agama, ilmu mu sosial, bahasa, ilmu - ilmu murni, ilmu - ilmu terapan, esenian, hiburan, olahraga (The Arts), kesusatraan, geografi, an sejarah umum.

Pn : agaimana keadaan pengunjung setiap harinya $?( \pm 50, \pm 40, \pm$ $0, \pm 20, \pm 10$ orang)

Pw : 60 orang/ hari. Karena, pihak Sekolah memberikan kebijakan unjungan wajib ke perpustakaan.

Pn : oleksi jenis apakah yang sering dibaca para pengunjung ?

Pw : uku Cerita

Dari kutipan wawancara di atas dapat peneliti simpulkan bahwa perpustakaan ini sudah dapat dimanfaatkan secara baik dan sudah ada menajemen untuk mengurusnya.

Dari kedua kutipan waawancara yang dilakukan oleh peneliti kepada guru Bahasa Indonesia dan Staf Pepustakaan dapat disimpulkan bahwa pemanfaatan sumber belajar perpustakaan pada mata pelajaran Bahasa Indonesia di MI Darussalam Pikatan Tahun Ajaran 2019/2020 kurang begitu maksimal karena kelengkapan koleksi perpustakaan tidak diimbangi dengan pelaksanaan $\mathrm{KBM}$ yang mempergunakan sumber belajar perpustakaan.

Sesuai rencana yang telah dijadwalkan, pertemuan pertama dilakukan pada hari Senin, 14 Januari 2013. Pada pertemuan tersebut 
peneliti mengisinya dengan pre test (tes awal). Pre test dilaksanakan untuk mengukur kemampuan membaca anak dan juga mengetahui kemampuan anak dalam menentukan kalimt utama. Pre test diikuti oleh 20 peserta didik kelas IV dan berlangsung dengan baik dan tertib. Hasil skor tes awal dapat diketahui bahwa rata-rata kemampuan membaca peserta didik ( KEM) adalah 67 kata per menit dan nilai skor tes awal peserta didik rata - rata adalah 49. Berdasarkan jawaban peserta didik pada tes awal terlihat bahwa kemampuan membaca rata - rata peserta didik tergolong rendah dan banyak yang belum memahami konsep awal dari materi kalimat utama.

\section{Paparan Data Pelaksanaan Tindakan (Siklus 1)}

Pelaksanaan tindakan terbagi kedalam empat tahap, yaitu tahap perencanaan, pelaksanaan, observasi, dan refleksi yang membentuk suatu siklus. Secara rinci, masing - masing tahap dapat dijelaskan sebagai berikut:

\section{a) Tahap Perencanaan}

Pada tahap ini kegiatan yang dilakukan oleh peneliti adalah sebagai berikut:

1) Menyiapkan rencana pembelajaran. Adapun rencana pembelajaran selengkapnya oleh peneliti dilampirkan pada bagian lampiran-lampiran skripsi.

2) Menyiapkan materi pembelajaran yang akan disajikan (Kalimat Utama)

3) Menyiapkan lembar observasi peneliti dan peserta didik

4) Melakukan koordinasi dengan guru Bahasa Indonesia mengenai pelaksanaan tindakan kelas.

\section{b. Tahap Pelaksanaan Tindakan}

Pelaksanaan tindakan pada siklus I ini dilaksanakan dalam 3 kali pertemuan yaitu tanggal 14,17 dan 21 Januari 2020 yang terdiri dari lima jam pelajaran. Karena pertemuan pertama hanya mempunyai waktu satu jam pelajaran, peneliti isi dengan perkenalan diri kepada peserta didik dan juga memperkenalkan materi kalimat utama. Pada kesempatan tersebut peneliti bertanya kepada peserta didik mengenai kalimat utama.

Pada pertemun yang kedua, peneliti menyampaikan tujuan pembelajaran yang ingin dicapai yaitu Peserta didik mampu menjelaskan 
pengertian Kalimat Utama serta Peserta didik mampu menunjukkan Kalimat Utama pada setiap paragraf beserta contohnya. Memasuki kegiatan Inti, peneliti memberikan beberapa contoh kalimat utama pada suatu paragraf. Peneliti mencoba memberikan dua paragraf yang kemudian peserta didik dicari kalimat utamanya. Dalam soal tersebut hanya dua anak yang mampu menyebutkan kalimat utama dengan baik dan tepat. Beberapa anak yang lain sudah berusaha namun masih terdapat kesalahan.

Setelah melakukan kuis, peneliti menerangkan materi dan meminta peserta didik agar memperhatikan serta bertanya jika ada materi yang belum dipahami. Kemudian peneliti melanjutkan membagikan soal latihan yang digunakan untuk mengukur kemampuan membaca dan ketepatan peserta didik dalam menentukan kalimat utama.

Dalam kegiatan KBM tersebut peneliti melakukan observasi peserta didik bersama dengan guru pembimbing dan teman sejawat untuk memperoleh informasi awal dengan harapan informasi tersebut dapat dijadikan landasan untuk melakukan kegiatan siklus selanjutnya.

Sebelum pelajaran diakhiri, peneliti menyampaikan kepada peserta didik bahwa pada pertemuan selanjutnya akan diadakan ujian (postest I) yaitu pada 21 Januari 2013. Peneliti meminta peserta didik untuk mempelajari materi Kalimat Utama di rumah agar pada pertemuan selanjutnya berjalan dengan baik. Dan peneliti juga menyampaikan bahwa pertemuan selanjutnya bertempat di ruang diskusi perpustakaan.

Pada pertemuan selanjutnya pada hari senin, 21 Januari 2020, kegiatan awal dimulai dengan memberi salam, memacu motivasi peserta didik dan mengingatkan tentang materi pada pertemuan yang lalu. Lalu dilanjutkan pada praktek percobaan mengenai kalimat utama. Percobaan tersebut antara lain dengan cara memerintahkan peserta didik untuk mencari buku pelajaran bahasa indonesia (selain buku yang digunakan dalam KBM). Setelah itu setiap peserta didik mencari sebuah bacaan yang ada pada buku tersebut lalu mencari kalimat utama pada setiap paragrafnya. Setelah percobaan selesai, peneliti melanjutkan dengan mengadakan post test I yang berlangsung selama 1 jam pelajaran. Post test ini berisi dari 3 bagian yaitu bagian pertama berisi bacaan sebanyak 420 
kata, bagian kedua berisi pertanyaan uraian yang berkaitan dengan bacaan. Bagian ketiga juga berisi uraian tetapi berkaitan dengan menentukan kalimat utama setiap paragraf pada bacaan di bagian pertama.

Pada bagian terakhir, peneliti membimbing peserta didik untuk membuat kesimpulan bersama mengenai materi Kalimat Utama yang telah mereka pelajari serta kesimpulan mengenai percobaan yang mereka lakukan bersama kelompok masing-masing.

Tes dalam penelitian ini dilaksanakan pada hari Senin tanggal 21 Januari 2020, dan dapat diketahui bahwa terjadi peningkatan nilai rata-rata peserta didik dari nilai rata-rata pre test 49 menjadi 63. Hal ini menunjukkan pemahaman peserta didik meningkat yang berarti meningkat pula hasil belajar mereka. Dalam siklus 1 ini 13 anak belum mencapai KKM pembelajaran Bahasa Indonesia yang ditetapkan pihak sekolah yaitu dengan nilai 75. Selain itu juga tingkat ketuntasan belajar peserta didik masih mencapai 30\%. Jika dilihat dari kemampuan Efektif membaca juga mengalami peningkatan walaupun hanya sedikit. Yakni dari rata - rata 67 kata per menit menjadi 73 kata per menit.

\section{c. Tahap Observasi}

Pengamatan dilakukan oleh 2 pengamat, yaitu Ibu Titin Muta'ati, S.Pd.I selaku guru Bahasa Indonesia MI Darussalam Pikatan sebagai pengamat 1 dan Alex Abdul Halim (teman sejawat STAIN Tulungagung) sebagai pengamat 2 . Pengamat 1 bertugas mengamati semua aktivitas guru dan pengamat 2 bertugas mengamati aktivitas peserta didik selama pembelajaran berlangsung. Pengamatan ini dilakukan sesuai dengan pedoman yang telah disediakan oleh peneliti. Hasil pengamatan terhadap aktifitas terlihat bahwa peneliti telah melakukan pembelajaran sesuai dengan rencana pembelajaran yang ada, meskipun ada beberapa poin yang tidak secara maksimal dilakukan oleh peneliti. Akan tetapi secara umum pembelajaran telah berlangsung secara optimal dan terkendali. Nilai yang diperoleh peneliti dari tabel observasi peneliti adalah 116 dari skor maksimal 150, sehingga dapat dihasilkan persentase nilai rata-rata $\frac{116}{150} \times 100 \%=77,3 \%$ 
Dari persentase nilai rata-rata yang mencapai $77,3 \%$ itu dapat diketahui taraf keberhasilan peneliti adalah baik. Hal tersebut sesuai dengan kriteria taraf keberhasilan tindakan sebagai berikut:

$75 \%<\mathrm{NR} \leq 100 \%$ : Sangat baik

$50 \%<\mathrm{NR} \leq 75 \% \quad:$ Baik

$25 \%<\mathrm{NR} \leq 50 \% \quad$ : Cukup baik

$0 \%<\mathrm{NR} \leq 25 \% \quad$ : Kurang baik.

Dari hasil pengamatan tersebut dapat dikatakan bahwa aktifitas yang dilakukan peneliti sudah sesuai dengan yang direncanakan. Hal ini menunjukkan bahwa peneliti benar - benar telah merencanakan dengan matang terkait pelaksanaan tindakan dalam penelitian.

\section{d. Tahap Refleksi}

Berdasarkan kegiatan refleksi terhadap hasil tes akhir, hasil pengamatan lapangan pada siklus 1 , maka dapat diperoleh beberapa hal berikut :

1. Hasil belajar peserta didik berdasarkan skor tes akhir menunjukkan peningkatan yang cukup baik dari tes sebelumnya. Hal ini menunjukkan bahwa pemahaman peserta didik terhadap materi pembelajaran semakin meningkat.

2. Aktivitas peserta didik telah menunjukkan tingkat keberhasilan pada kriteria baik. Oleh karena itu tidak perlu pengulangan siklus untuk aktivitas peserta didik .

3. Kegiatan pembelajaran menunjukkan penggunaan waktu yang sudah sesuai dengan rencana. Oleh sebab itu, tidak diperlukan pengulangan siklus untuk mengatur waktu.

4. Kegiatan pembelajaran telah menunjukkan keaktifan peserta didik dalam kegiatan pembelajaran, akan tetapi perlu dilakukan siklus 2, karena rata - rata skor belum mencapai standar KKM yaitu 75. Jadi jelas perlu dilakukan siklus 2 untuk meningkatkan hasil belajar peserta didik .

5. Disamping itu, walaupun Kemampuan Efektif Membaca sudah meningkat akan akan tetapi hal itu belumlah signifikan sehingga perlu dilakukan pengetesan ulang agar menunjukkan pemanfaatan perpustakaan dapat meningkatkan keterampilan membaca peserta didik kelas IV MI Darussalam Pikatan. 


\section{e. Temuan Penelitian}

Beberapa temuan penelitian yang diperoleh dari pelaksanaan penelitian adalah sebagai berikut :

1. Dengan memanfaatkan sumber belajar perpustakaan, semakin meningkatkan kemampuan peserta didik dalam memahami materi yang diberikan. Hal ini menunjukkan adanya peningkatan pemahaman peserta didik.

2. Melalui pembelajaran dengan Pemanfaatan Sumber Belajar Perpustakaandapat meningkatkan hasil belajar dalam proses pembelajaran.

3. Peserta didik merasa senang dengan pembelajaran ini karena selain bisa meningkatkan pemahaman terhadap materi, juga dapat meningkatkan keaktifan, antusias dan perhatian peserta didik dalam belajar.

4. Dengan Pemanfaatan Sumber Belajar Perpustakaan keterampilan membaca peserta didik MI Darussalam Pikatanpada mata pelajaran Bahasa Indonesia meningkat.

\section{Pembahasan}

Fokus dalam penelitian ini adalah pemanfaatan sumber belajar perpustakaan untuk meningkatkan keterampilan membaca pada pembelajaran Bahasa Indonesia dengan materi tentang kalimat utama.

Penelitian ini dilakukan dengan dua siklus, siklus pertama dilaksanakan tiga kali pertemuan dan siklus kedua dilaksanakan dua kali pertemuan, hal ini mengingat materi yang akan diajarkan hanya kalimat utama. Siklus pertama, pada pertemuan pertama peneliti melaksanakan pemeriksaan lapangan serta memberikan pre-test dan memberikan pengenalan mengenai materi yang akan diajarkan dengan menggunakan strategi pembelajaran konvensional yakni metode ceramah dan Tanya jawab. Guru menjelaskan dengan mendekte di depan kelas, sedangkan peserta didik mendengarkan dan menulis apa yang diperintahkan guru, serta diselingi tanya jawab.

Melalui pre-testpeneliti dapat mengetahui bahwa tingkat pemahaman peserta didik mengenai materi kalimat utama masih kurang dan dengan menggunakan pre-testpeneliti juga dapat mengetahui tingkat Kemampuan Efektif Membaca (KEM) awal pada peserta didik. Disamping itu pada 
pengenalan materi yang dilakukan peneliti, terlihat pembelajaran konvensional dengan metode ceramah dan tanya jawab menjadikan peserta didik pasif dan menjadikan guru sebagai satu-satunya pentransfer ilmu. Peserta didik tidak dituntut untuk mencari sendiri dan memecahkan masalah dalam kegiatan pembelajaran. Sehingga peserta didik cenderung tidak semangat dan keterampilan membaca peserta didik sangat rendah, karena hanya menjadi pendengar saja dan tidak terlalu ikut andil dalam pembelajaran.

Dari hasil pertemuan pertama yang telah dilaksanakan, peserta didik tampak kurang antusias dan kurang berminat dalam pembelajaran Bahasa Indonesia. Jadi pembelajaran yang kurang melibatkan peserta didik dalam kegiatan pembelajaran akan menimbulkan rasa terpaksa, tertekan, bosan dan malas. Sehingga mengakibatkan keterampilan membaca peserta didik menjadi kurang begitu terasah dengan baik disamping itu hasil belajar juga dilihat sangat kurang. Jadi sudah jelas bahwa kegiatan belajar mengajar yang hanya mengandalkan informasi guru tanpa sumber atau media belajar yang digunakan sangat tidak kondusif apalagi diterapkan dalam kegiatan pembelajaran yang cenderung membutuhkan realita dan latihan langsung seperti pelajaran Bahasa Indonesia.

Salah satu cara menciptakan lingkungan belajar yang menyenangkan dalam pembelajaran Bahasa Indonesia khususnya pada materi kalimat utama adalah dengan menggunakan sumber belajar perpustakaan. Dimana sumber belajar tersebut diharapkan mampu menggugah semangat dan meningkatkan keterampilan membaca peserta didik dalam pembelajaran. Karena dengan sumber belajar tersebut peserta didik dapat melihat kejadian kalimat utama secara kongkrit, bukan hanya sekedar mengetahui dari satu buku paket atau satu sumber saja.

Menyikapi hasil pre-test, pada pertemuan selanjutnya peneliti menggunakan sumber belajar perpustakaan. Dengan menggunakan sumber belajar ini diharapkan peserta didik mampu berperan aktif dalam mengikuti pembelajaran Bahasa Indonesia. Dengan sumber belajar perpustakaan kebutuhan berbagai program pendidikan dapat dipenuhi dengan baik, berbagai sumber informasi yang tidak mungkin diberikan melalui sumber belajar lainnya dapat disajikan melalui perpustakaan. 
Dengan menggunakan sumber belajar tersebut dalam pertemuan ketiga pada siklus pertama ini ternyata menjadikan peserta didik lebih berani mengungkapkan pendapatnya dan lebih bersemangat dibanding dengan pertemuan sebelumnya. Ada keinginan untuk belajar Bahasa Indonesiayang ditunjukkan dengan mengungkapkan pendapat dan bertanya walaupun sebagian besar masih didominasi oleh peserta didik yang aktif. Tapi dalam pertemuan selanjutnya mulai nampak peningkatan keetektifan peserta didik secara keseluruhan.

Hasil post testsiklus pertama dan kedua yang dilakukan menunjukkan terjadi peningkatan keterampilan membaca. Keterampilan membaca tersebut dapat diukur dengan cara mencari Kemampuan Efektif Membaca (KEM). Pada saat pre-test rata - rata KEM adalah 67 kata per menit. KEM meningkat pada post test siklus pertama dengan rata - rata 73 kata per menit dan meningkat lagi secara signifikan pada siklus kedua dengan 106 kata per menit.

Sedangkan hasil pengamatan menunjukkan pemanfaatan sumber belajar perpustakaan mampu meningkatkan keterampilan membaca peserta didik. Hal itu disebabkan pemanfaatan perpustakaan sangat sesuai dengan materi yang diajarkan yaitu tentang kalimat utama dengan membaca intensif. Sedangkan bukti yang lainnya adalah pernyataan peserta didik yang mengatakan senang terhadap pemanfaatan sumber belajar perpustakaan, sehingga kelas lebih hidup dan peserta didik mulai bersemangat yang ditunjukkan muka sangat ceria dan lebih antusias dalam mengikuti pelajaran Bahasa Indonesia.

Sudah sangat jelas bahwa pemanfaatan sumber belajar perpustakaan yang diterapkan oleh peneliti pada pembelajaran Bahasa Indonesia pada materi kalimat utama, dapat meningkatkan keterampilan membaca peserta didik. Hal ini selaras dengan hasil observasi saat pembelajaran berlangsung. Peserta didik sangat antusias dan semangat dalam mengikuti pelajaran. Tidak ada rasa bosan dan jenuh, karena peserta didik terlibat secara aktif dalam kegiatan pembelajaran.

Adapun indikator keberhasilan pemanfaatansumber belajar perpustakaan sebagai berikut:

1. Pada saat pembelajaran peserta didik terlihat lebih aktif untuk mencari sendiri, semangat dan tidak merasa bosan pada saat pembelajaran berlangsung. 
2. Dengan memanfaatkan perpustakaan peserta didik bisa melihat kalimat utama secara langsung di buku dan lebih konsentrasi pelajaran yang dipelajari.

3. Adanya peningkatan keterampilan membaca peserta didik terlihat pada saat observasi yang dilakukan oleh peneliti , test KEM (Kemampuan Efektif Membaca) dan juga hasil belajar yang dilakukan.

\section{Penutup}

Dari deskripsi hasil paparan data yang telah diuraikan dalam bab IV, maka dapat disimpulkan sebagai berikut:

1. Pemanfaatan sumber belajar perpustakaan pada mata pelajaran Bahasa Indonesia di MI Darussalam Pikatantahun ajaran 2012-2013 sudah dimanfaatkan secara baik walaupun belum dimaksimalkan secara baik pada proses belajar mengajar terutama Bahasa Indonesia.

2. Terjadi peningkatan keterampilan membaca peserta didik kelas IV MI Darussalam Pikatanmelaluipemanfaatan sumber belajar perpustakaan pada pelajaran Bahasa Indonesia materi kalimatutama. Hal ini dapat dilihat dari pengukuran Kemampuan Efektif Membaca (KEM) yang dilakukan peneliti dari pretest yang hanya mencapai rata - rata 67 kata per menit meningkat pada post test siklus pertama dengan 73 kata per menit dan naik secara singnifikan pada siklus kedua dengan 106 kata per menit. Hasil belajar peserta didik juga meningkat dari rata-rata hasil belajar peserta didik pada pretest 49 meningkat pada posttestsiklus pertama dengan 63 dan posttestsiklus kedua yang mencapai nilai rata-rata peserta didik dengan 81 . Dengan demikian, membuktikan bahwa pemanfaatan sumber belajar perpustakaan dapat meningkatkan hasil belajar Bahasa Indonesia peserta didik kelas IV MI Darussalam Pikatan. 


\section{Daftar Pustaka}

Abdurrahman, M. Pendidikan Bagi Anak Berkesulitan Belajar. Jakarta : Rineka Cipta. 1999.

Akbar,Sa'dun.Penelitian Tindakan Kelas, (Filosofi, Metodologi, dan Implementasinya, Malang: Surya Pena Gemilang. 2008

Alwi, Hasan. et.all. Tata bahasa Indonesia. Jakarta : Balai Pustaka. 2000)

Arikunto,Suharsimi. dkk. Penelitian Tindakan Kelas, Jakarta: Bumi Aksara. 2007.

Prosedur Peneltian Suatu Pendekatan Praktik.Jakarta: Rineka Cipta. 2008.

Asrori,MohammadPenelitian Tindakan Kelas. Bandung: Wacana Prima. . 2007.

Bafadal, Ibrahim. Pengelolaan Perpustakaan Sekolah. Jakarta : Bumi Aksara. 2001.

.Manajemen Perlengkapan Sekolah teori dan Aplikasinya. Jakarta : Bumi aksara. 2004.

Broto. Pengajaran Bahasa Indonesia. Jakarta : Bulan Bintang.1978.

Cahyani, Isah..Pembelajaran Bahasa Indonesia. Jakarta : Direktorat Jendral Pendidikan Islam Departemen Agama Republik Indonesia.2009.

Chaer, Abdul. Leonie Agustina. Sosiolinguistik Perkenalan Awal.Jakarta: Rineka Cipta. 2010.

Chaer, Abdul. Tata Bahasa Praktis Bahasa Indonesia.Jakarta : PT Rineka Cipta. 2006.

Cooper, Coral. Penerjemah : Nadia Lastiani.Ensklopedia Pengembangan Anak. Judul Asli :Your Child year by Year. Jakarta : Erlangga. 2008. 
Darmono.Perpustakaan Sekolah : Pendekatan Aspek Manajemen dan TataKerja. Jakarta : Grasindo. 2008.

Darmono. Pengembangan Perpustakaan Sekolah Sebagai Sumber Belajar. (Jurnal Perpustakaan Sekolah. Tahun 2007 Nomor I - April).

Degeng, I.N.S.. Strategi Pembelajaran Mengorganisasi Isi dengan Model Elaborasi. Malang: IKIP dan IPTDI.1997.

Departemen pendidikan dan kebudayaan. Garis - Garis Besar Program Pengajaran Bahasa Indonesia : Pendidikan Dasar. Jakarta :Departemen pendidikan dan kebudayaan. 1993.

Departemen pendidikan dan kebudayaan. Pedoman Proses Belajar Mengajar di $S D$. Jakarta: Proyek Pembinaan Sekolah Dasar. 1995.

Dinas Pendidikan Dan kebudayaan.Pedoman Guru Menuju Pembelajaran Tuntas Bahasa Indonesia Kelas IV. Sukoharjo : CV Sindunata. 2012.

E. Mulyasa.Kurikulum Berbasis Kompetensi. Bandung: PT. Remaja Rosdakarya. 2003.

. Standar Kompetensi dan Sertifikasi Guru. Bandung : PT Remaja Rosdakrya. 2007.

E. Zainal arifin. Cermat Berbahasa Indonesia. Jakarta : Mediyatama Sarana Perkasa. 1988.

Fauzi,Taufik.PERPUSDOKINFO : Suatu Pengantar: Dalam Manajemen Informasi Sistem. Surabaya : Bintang. 2009.

Furchan, Arief. Pengantar Penelitian dalam Pendidikan.Surabaya: Usaha Nasional. $t t$

Furqonul, Azies. Alwasilah A. Chaedar.Pengajaran Bahasa Komunikatif: Teori dan Praktek. Bandung: Remaja Rosdakarya. 1996.

Guntur, Henry . Tarigan. Membaca sebagai Suatu Keterampilan Berbahasa. (Bandung: Angkasa. 1986. 
Hadi,Mahsus. Pemanfaatan Media Visual (Gambar) Dalam Meningkatkan Minat Membaca Siswa Kelas IV Di SDN II Betak Kec. Kalidawir Kab. Tulungagung Tahun Pelajaran 2010 - 2011 (Tulungagung : Skripsi Tidak Diterbitkan). 2011.

Halimah, Lely. Pemberdayaan Lingkungan Sebagai Sumber Belajar dalam Upaya Meningkatkan Kompetensi Berbahasa Indonesia Siswa Kelas 4 SD Laboratorium UPI Kampus Cibiru (JURNAL, Pendidikan Dasar, Nomor: 10 - Oktober).2008).

Hasan,M. Iqbal. Pokok Materi Metodologi Penelitian Dan Amplikasinya Jakarta: Ghalia Indonesia. 2002.

Komalasari,Kokom. Pembelajaran Kontekstual. Bandung : PT Rafika Aditama. 2001.

Masykur,Moch. Mathematical Intelegence.Yogyakarta : Ar Ruzz Media. 2007.

Moleong,Lexy. Metodologi Penelitian Kualitatif.Bandung: PT. Remaja Rosdakarya. 2002.

Mulyasa. Kurikulum Berbasis kompetensi. Bandung: PT. Remaja Rosdakarya. 2005.

Mulayati, Yeti. Bahasa Indonesia. Jakarta : Universitas Terbuka. 2010.

Muslich,Masnur. Melaksanakan PTK itu Mudah.Jakarta: Bumi Aksara

Purwanto,Ngalim. Prinsip-Prinsip dan Teknik Evaluasi Pengajaran. Bandung: Remaja Rosdakarya. 2006.

Purwono, Sri Suharsimi. Perpustakaan dan kepustakawanan Indonesia. Jakarta :Universitas Terbuka. 2010.

Rahim, Farida. Pengajaran Membaca di Sekolah Dasar. Jakarta : Bumi Aksara. 2008. 
Rofi'uddin, Ahmad dan Zuhdi, Darmiyati. Pendidikan Bahasa dan Sastra Indonesia di KelasTinggi. Jakarta: Depdikbud. 1999.

Safi'I, Asrop. Metodologi Penelitian Pendidikan, Surabaya: Elkaf. 2005.

Sandjaja, S.. Hubungan Antara Kemampuan Persepsi Visual Dan Tingkat Pendidikan Orangtua Dengan Kemampuan Membaca Di SD Kanisius Semarang Barat. Tesis (Tidak Diterbitkan) Yogyakarta : Program Pasca Sarjana Universitas Gajah Mada. 1993)

Sinaga. Pengelolaan Perpustakaan Sekolah. Jakarta : Kiblat buku Utama. 2007.

Soedarso. Speed Reading: System Membaca Cepat Dan Efektif. Jakarta : PT Gramedia Pustaka Utama. 2002.

Sudarsana, Undang . Bastiano. Pengembangan Minat Baca.Jakarta : Universitas Terbuka. 2010.

Sugiyono. Metodologi Penelitian Kuantitatif dan Kualitatif. Bandung: Alfabeta. 2008.

Suhardjono. Penelitian Tindakan Kelas Sebagai Kegiatan Pengambangan Profesi Guru.Jakarta: PT Bumi Aksara. 2007.

Sujana,Nana. (2006). Penilaian hasil proses belajar mengajar.Bandung: Remaja Rosdakarya

Sukardi. Metodologi Penelitian Pendidikan. Jakarta: Bumi Aksara. . 2007.

Sumardi. Buku Pelajaran Bahasa Indonesia SD : Sebagai Sarana Pengembangan Kepribadian, Penalaran, Kreativitas, Dan Keterampilan Anak. Jakarta : PT. Grasindo. 2000.

Sutarno NS. Perpustakaan dan Masyarakat.Jakarta: CV. Sagung Seto. 2006.

Suroso. Penelitian Tindakan Kelas.Yogyakarta: Pararaton. 2009.

Susilo. Penelitian Tindakan Kelas. Yogyakarta: Pustaka Book Publisher. 2007. 
Tanzeh,Ahmad. Metodologi Penelitian Praktis, Yogyakarta: Penerbit Teras. 2011.

Wiriaatmadja,Rochiati. Metodologi Penelitian TIndakan Kelas Untuk Meningkatkan Kinerja Guru dan Dosen.Bandung: PT Remaja Rosdakarya. 2005.

Yuli Eko Siswono,Tatag. Mengajar dan Meneliti Panduan PTK untuk Guru dan Calon Guru. Surabaya: Unesa University Press. 2008.

Zuriah,Nurul. Metodologi Penelitian Sosial dan Pendidikan. Jakarta: Bumi Aksara. 2006.

Wahidmurni. Penelitian Tindakan Kelas (dari Teori Menuju Praktek).Malang: UM Press. 2008.

Mayasa..http://m4y-a5a.blogspot.com/2012/05/hakikat-membaca.html (diakses :28/06/2012). 2012.

Anonim. (tt). Hakikat Pembelajaran dan Siswa Sekolah Dasar. http://massofa.wordpress.com/2010/12/09/kajian-proses-pembelajaranbahasa-indonesia-di-sd/ diakses (21/10/2012)

Anonim. (tt). Pemanfaatan Perpustakaan Sebagai Sumber Belajar.http://meretasmasadepan.blogspot.com/2011/03/pemanfaatanperpustakaan-sebagai-sumber.html (diakses : 27/06/2012)

Anonim. (tt). Perpustakaan Sebagai Media Pembelajaran. http://nurilsb.wordpress.com/2011/05/09/dunia-maya/ (diakses : 27/06/2012)

Anonim (2010).Perpustakaan Sebagai Pusat Belajar.http://sembilan juli.blogspot.com/2010/05/pemanfaatan-perpustakaan-sebagaipusat.html diakses $(21 / 10 / 2012)$ 
Membaca Pada Mata Pelajaran Bahasa Indonesia Peserta Didik Kelas IV MI

Darussalam Pikatan Tahun Pelajaran2019/2020

Copyright (C) 2020Journal Dirasah: Vol. 3, No.2,Agustus 2020, p-ISSN: 2615-0212, e-ISSN;

2621-2838

Copyright rests with the authors

Copyright of Jurnal Dirasah is the property of Jurnal Dirasah and its content may not be copied oremailed to multiple sites or posted to a listserv without the copyright holder's express writtenpermission. However, users may print, download, or email articles for individual use.

https://ejournal.iaifa.ac.id/index.php/dirasah

Dirasah, Vol.3, No. 2, Agustus 2020 